УДК $336.763: 35.316$

DOI: $10.15673 /$ fie.v11i1.1300

\author{
Горбаневич В.Л. \\ аспірант \\ кафедра фрінансів, банківської справи та страхування \\ Львівський торговельно-економічний університет \\ вул. Туган-Барановського, 10, м. Львів, 79000 \\ E-mail: vetal11gl@gmail.com \\ Іванюта П.В. \\ доктор наук з державного управління, доцент \\ кафедра менеджменту \\ Вінницький кооперативний інститут \\ вул. Академіка Янгеля, 59, м. Вінниця, 21009 \\ E-mail: ur6hdc@gmail.com
}

\title{
РОЛЬ РИНКУ ЦІННИХ ПАПЕРІВ В ЕКОНОМІЦІ ДЕРЖАВИ (НА ПРИКЛАДІ США)
}

Обґрунтована необхідність дослідження ринку цінних паперів, що полягає у розкритті процесів функціонування ринкових відносин в економіці держави, де основна увага приділяється зміні відсоткових ставок, вартості грошей та цінних паперів, кредитної політики комерційних банків тощо, які відображаються на економіці держави - на прикладі США.

Сутність функціонування ринку цінних паперів у США полягає у тому, що він поділяється на біржовий і позабіржовий, або, іншими словами, первинний і вторинний ринки. А стан функціонування ринку цінних паперів у США на сьогоднішній день відображає ті реалії і фундаментальні принципи, якими були побудовані фрінансові ринки у 50 - 90-ті рр. XX ст. Саме це вищезазначене й уповільнює стрімку перебудову й осучаснення фінансових ринків, властиве для останніх кількох років.

Також слід зазначити особливості державного регулювання ринку цінних паперів у США, що полягають у втручанні у діяльність фондових бірж та виділення коштів для активізації кредитних операцій спільно з банківськими установами.

Ключові слова: цінні папери, акції, банки, фондовий ринок, економіка.

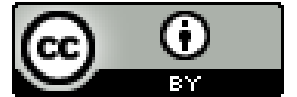

This work is licensed under a Creative Commons Attribution 4.0 International License http://creativecommons.org/licenses/by/4.0/
Постановка проблеми та ії зв'язок 3 важливими науковими та практичними завданнями. Ознакою існування ринку цінних паперів $\epsilon$ та сфера й відносини у кожній країні подібно до ринку товарів і послуг, де важливе призначення полягає у задоволенні економічних інтересів учасників грошово-торговельних відносин за рахунок обороту, випуску цінних паперів за різними видами, як акція, облігація, вексель, і їх обіг шляхом розміщення на торгах як пропозиція щодо їх продажу на спеціалізованій біржі. Але проблема полягає у дослідженні процесів функціонування ринку цінних паперів і його впливу на економічну систему держави у вигляді джерел постачання грошовими коштами. Практична значимість дослідження процесів, які відбуваються на ринку цінних паперів у США, полягає в удосконаленні біржової діяльності в Україні через перегляд операцій 3 цінними паперами, оптимізація відсоткових ставок та поліпшення кредитування всіх сфер економіки держави.

Аналіз останніх публікацій по проблемі. В першу чергу, доцільно приділити основну увагу публікаціям Джозефа Юджина Стігліца, який розкривав причини нерівності у суспільстві, що відбуваються у державах, де виділив особливу роль недолікам і проблемам функціонування ринку цінних паперів і впливу державного управління на нього у США. А що стосується грошово-торговельних відносин на ринку цінних паперів, то слід відзначити наукові праці Гоха Лео, Льюїса, М., Поважного О.С., Рубцова Б.Б., Царенка О.М. Хагстром Р., та ін. Так, Роберт Хагстром обгрунтовував роль цінності грошових коштів у проведенні торгів на фондовій біржі, Майкл Льюїс особливу увагу приділяв впливу зовнішніх факторів, як політичної ситуації i економічних процесів у просторі та часі на діяльність фондових бірж i котирування вартостей цінних паперів і грошей в ньому, Лео Гох розкривав причини участі емітентів, інвесторів та комерційних банків у фондовій біржі та проведенні ними торгів.

Але виникає необхідність більш детального дослідження стану і тенденцій економічної системи держави за рахунок грошово-торговельних відносин на фондовому ринку. 
Формулювання цілей дослідження полягає у розкритті процесів функціонування ринку цінних паперів у державі на прикладі США. Для досягнення встановленої мети необхідно виконати такі завдання:

- обгрунтування впливу ринку цінних паперів на соціально-економічну систему держави;

- дослідження процесів коливань вартості грошової маси та відсоткових ставок;

- узагальнення операцій з цінними паперами у процесі грошово-торговельних відносин.

Виклад основних результатів та їх обгрунтування. Як твердить Стігліц з баченням того, що через підвищення рівня життя та доходів американців відбувається зміна економічної системи у державі. Сполучені штати Америки будували модель економічної системи на двох основах: міжнародно-валютній системі та зоні вільної торгівлі. Після цього наступною моделлю економічної системи США є «Золотий стандарт», що побудований у 1944 році, де грошова одиниця «долар» отримала роль основної валюти світової системи [1]. Тоді у Федеральної резервної системи була змога випускати долари на потреби економіки.

Крім цього, США також є першою країною у світі, де започаткувався фондовий ринок у вигляді біржової торгівлі, де здійснюються операції учасників 3 з купівлі-продажу цінних паперів та фінансових інструментів.

Але новизна питань щодо дослідження фондового ринку, операцій на фондовій біржі щодо цінних паперів й фінансових інструментів під час їх обігу та розміщення у спеціалізованих платформах полягає у обгрунтуванні впливу економічних та політичних процесів, які відбуваються в країні, а також поза нею в тому разі і тих тенденцій, які іiі стосуються. Тому що ці тенденції впливають на вартість цінних паперів та фінансових інструментів у процесі їх обігу на фондовій біржі. Ця новизна також полягає у дослідженні стану фінансової політики й регулювання органів державної влади, які також впливають на фондовий ринок країни.

Фондова біржа - це організаційно оформлений, постійно діючий ринок, на якому здійснюється торгівля цінними паперами та фінансовими інструментами, де задіяні не лише біржові працівники та спеціалісти 3 оцінки вартостей цінних паперів та фінансових інструментів, але й всі галузі економічної діяльності та суспільні сфери, які існують та відбуваються у країні. Звісно, фондова біржа має відповідну інфраструктуру, відповідне технічне та інформаційне забезпечення, вимоги до іï учасників i регламентований порядок щодо іiі проведення.

А діяльність фондової біржі уособлюється операціями 3 цінними паперами та документамиугодами, а також 3 їх обігом та розміщенням, що відображають вартісні та ціннісні характеристики таких об'єктів, які грають важливу роль у економічних відносинах держави та задіяні у процесі економічного відтворення. До таких об'єктів відносяться як сфери діяльності й відтворення (підприємства, банківські установи та ін.), речові предмети (картини, скульптури, коштовності, метали та ін.), а також корисні копалини (золото, платина, нафта й газ та ін.). Тут доцільно зазначити, що операції з обігом та розміщенням цінних паперів та фінансових документів формують матеріальну форму їх відносин на фондовій біржі та в обов'язковому порядку регламентують юридичне право власника на вищезазначені об'єкти.

Обіг цінних паперів - вчинення правочинів (угод), пов'язаних 3 переходом прав власності на цінні папери і прав за цінними паперами, за винятком договорів, що укладаються в період розміщення цінних паперів.

Розміщення цінних паперів - це відчуження цінних паперів емітентом або андеррайтером шляхом укладення цивільно-правового договору 3 першим власником. 3 поняттям розміщення цінних паперів тісно пов'язаний термін «андеррайтинг» - розміщення (підписка, продаж) цінних паперів торговцем цінними паперами за дорученням, від імені та за рахунок емітента.

Угода з цінними паперами - дія, спрямована на встановлення, зміну або припинення цивільних прав та обов'язків у зв'язку зі зверненням цінних паперів. Найпоширеніший вид угоди - договір. Розрізняють угоди: односторонні (наприклад, заповіт), двосторонні і багатосторонні.

Для правильного розуміння механізмів фондового ринку, вмілого застосування цінних паперів у господарській практиці суб'єктами підприємницької діяльності важливо правильно класифікувати відносини 3 цінних паперів. А класифікація відносин 3 цінних паперів проводиться такими групами:

1) економічні відносини, які формуються між суб'єктами ринку в зв'язку з отриманням доходу, нарахуванням податків або зборів, оплатою витрат обігу та обслуговування цінних паперів;

2) відносини власності, що виникають у зв'язку 3 придбанням або відчуженням цінних паперів, переходом права власності на неї від однієї особи до іншої, і є найскладнішою, слабо вивченою групою відносин сучасного ринку;

3) організаційно-правові відносини, які складаються 3 взаємних прав, обов'язків суб'єктів i учасників ринку в зв'язку з проведенням різних операцій з цінними паперами;

4) соціальні - це особлива група відносин, взаємопов'язаних 3 функціонуванням соціальної інфраструктури суб'єктів ринку (емітентів цінних паперів, професійних учасників та інвесторів);

5) етичні відносини, зумовлені необхідністю вибору дій або прийняття рішень за окремими операціями з цінними паперами, які зачіпають, а іноді обмежують інтереси інших суб'єктів відносин;

6) інформаційні відносини - випливають 3 обробки інформаційних даних ринку спеціалізованими засобами та технологіями. Особливістю цієї групи відносин виступає конфіденційний характер більшої частини даних про 
фондовий ринок, його учасників і угодах 3 цінними паперами;

7) психологічні та інші відносини, які можна виділити в процесі обігу цінних паперів.

Відповідно до Закону України «Про цінні папери та фондовий ринок», цінні папери документи встановленої форми 3 відповідними реквізитами, що посвідчують грошові або інші майнові права, визначають взаємовідносини особи, яка i їх розмістила (видала), i власника, та передбачають виконання зобов'язань згідно 3 умовами їх розміщення, а також можливість передачі прав, що випливають із цих документів, іншим особам [12].

У цьому визначенні можна виділити такі відмітні ознаки цінних паперів:

- це грошові документи;

- підтверджують право володіння чи відносини позики;

- передбачають виплату доходу у вигляді відсотків чи дивідендів;

- передбачають можливість передачі грошових та інших прав.

При ухваленні інвестиційних рішень здійснюються різні вартісні оцінки цінних паперів. У практичній діяльності розрізняють наступні їх види:

- номінальна вартість;

- емісійна вартість (ціна розміщення);

- бухгалтерська (балансова, книжна) вартість (лише стосовно вартості акцій акціонерних товариств);

- ринкова вартість;

- курсова вартість.

Номінальна вартість цінного паперу - це вартість, вказана на лиці цінного паперу або його сертифікату.
В процесі свого розвитку будь-яке підприємство, що $\epsilon$ акціонерним товариством, періодично вдається до емісії цінних паперів з метою отримання додаткового капіталу. Ціна, за якою реалізуються цінні папери нового випуску, називається ціною розміщення (емісійною ціною).

Балансова вартість зазвичай розраховується щокварталу і в кінці року при складанні балансу.

За українським законодавством розміщення цінного паперу має здійснюватися за ринковою ціною, яка може відрізнятися від номінальної, якщо в процесі звернення на вторинному ринку операції 3 купівлі-продажу цінних паперів можуть здійснюватися за ціною вище або нижче їх номінальної вартості, то при емісії цінного паперу ціна його розміщення має бути не нижче номінальної.

Ринкова ціна - це ціна, за якою цінний папір купується і продається на вторинному ринку. Ця ціна формується під впливом ринкової кон'юнктури i визначається попитом i пропозицією, рівнем прибутковості на суміжних сегментах фінансового ринку, інфляційними очікуваннями й іншими чинниками. Ринкова ціна зазвичай встановлюється на торгах на фондовій біржі і відображає дійсну ціну цінного паперу за умови великого обсягу операцій.

А ринкова ціна 3 розрахунку на 100 грошових одиниць (г.о.) номіналу називається курсом (курсовою вартістю).

Методологічними положеннями операцій у фондовій біржі є порівняння учасниками біржових торгів вартісних властивостей цінних паперів та фінансових документів, які залучаються до обігу та розміщення на спеціалізованих платформах (майданчиками) відображають вагому частину біржової інфраструктури за їх класифікаційними ознаками (табл.1) [2, с. 56].

Таблица 1

Порівняльні характеристики цінних паперів і фінансових документів, які задіяні на фондовій біржі [2]

\begin{tabular}{|c|c|c|c|c|}
\hline № $3 / \Pi$ & Вид & Тип & Категорія & Форма \\
\hline 1 & Акція & $\begin{array}{l}\text { Іменні. } \\
\text { На пред’явника }\end{array}$ & $\begin{array}{l}\text { Прості. } \\
\text { Привілейовані }\end{array}$ & $\begin{array}{l}\text { Документарна. } \\
\text { Бездокументарна }\end{array}$ \\
\hline 2 & $\begin{array}{l}\text { Облігації зовнішніх державних } \\
\text { позик }\end{array}$ & $\begin{array}{l}\text { Іменні. } \\
\text { На пред’явника }\end{array}$ & Прості & $\begin{array}{l}\text { Документарна. } \\
\text { Бездокументарна }\end{array}$ \\
\hline 3 & $\begin{array}{l}\text { Облігації внутрішніх і місцевих } \\
\text { позик }\end{array}$ & На пред’явника & Прості & $\begin{array}{l}\text { Документарна. } \\
\text { Бездокументарна }\end{array}$ \\
\hline 4 & Облігації підприємств & $\begin{array}{l}\text { Іменні. } \\
\text { На пред’явника }\end{array}$ & Прості & $\begin{array}{l}\text { Документарна. } \\
\text { Бездокументарна }\end{array}$ \\
\hline 5 & Ощадні сертифікати & $\begin{array}{l}\text { Іменні. } \\
\text { На пред’явника. }\end{array}$ & Прості & $\begin{array}{l}\text { Документарна. } \\
\text { Бездокументарна }\end{array}$ \\
\hline 6 & Вексель & - & - & Документарна \\
\hline 7 & Приватизаційні папери & Іменні & - & $\begin{array}{l}\text { Документарна. } \\
\text { Бездокументарна }\end{array}$ \\
\hline 8 & $\begin{array}{l}\text { Інвестиційні сертифікати } \\
\text { закритого фонду }\end{array}$ & $\begin{array}{l}\text { Іменні. } \\
\text { На пред’явника. }\end{array}$ & Мають вільний обіг. & $\begin{array}{l}\text { Документарна. } \\
\text { Бездокументарна }\end{array}$ \\
\hline 9 & $\begin{array}{l}\text { Інвестиційні сертифікати } \\
\text { відкритого фонду }\end{array}$ & $\begin{array}{l}\text { Іменні. } \\
\text { На пред’явника. }\end{array}$ & $\begin{array}{l}\text { Заборонені для } \\
\text { вільного обігу }\end{array}$ & $\begin{array}{l}\text { Документарна. } \\
\text { Бездокументарна }\end{array}$ \\
\hline 10 & Казначейські зобов’язання & $\begin{array}{l}\text { Іменні. } \\
\text { На пред’явника. }\end{array}$ & - & $\begin{array}{l}\text { Документарна. } \\
\text { Бездокументарна }\end{array}$ \\
\hline
\end{tabular}


Продовження табл. 1

\begin{tabular}{|c|c|c|c|c|}
\hline & & & & Продовження табл. \\
\hline № $3 / \Pi$ & Вид & Тип & Категорія & Форма \\
\hline 11 & Заставні документи & $\begin{array}{l}\text { Іменні. } \\
\text { На пред'явника. }\end{array}$ & - & $\begin{array}{l}\text { Документарна. } \\
\text { Бездокументарна }\end{array}$ \\
\hline 12 & Іпотечні документи & $\begin{array}{l}\text { Іменні. } \\
\text { На пред’явника. }\end{array}$ & - & $\begin{array}{l}\text { Документарна. } \\
\text { Бездокументарна }\end{array}$ \\
\hline 13 & $\begin{array}{l}\text { Біржові угоди (опціон, ф’ючерс, } \\
\text { дериватив) }\end{array}$ & - & - & - \\
\hline
\end{tabular}

Вартість курсів цінних паперів оцінюється за допомогою фондових індексів, які використовуються в різних країнах світу. Всі фондові індекси характеризують динаміку курсів акцій національних емітентів, мають різну базу, часто розраховуються за різними методиками і тому непорівнянні. Наприклад, у США є такі фондові індекси, як: Індекси: «Стандард енд Пурз 500» «Стандард енд Пурз 100», Промисловий індекс Доу-Джонса, а також такі композитні індекси, як Нью-Йоркської фондової біржі і NASDAQ.

Фінансові інструменти можна класифікувати, беручи як класифікаційну ознаку щодо особливостей відносин клієнта та оферента, а також сегмент, на якому здійснюється обіг цінного папера, строк поставки тощо.

Загальний вигляд фінансового інструменту має контракт, що має свою ціну та строк його виконання, який має юридичну силу.

Тому слід розглянута такі класифікаційні ознаки фінансових інструментів:

I. Виходячи 3 першої ознаки фінансові інструменти поділяють на реальні (основні, базові), ціни або курси на які визначаються на ринку через взаємодію попиту й пропонування, та похідні, ціни на які $є$ похідними від цін базового активу (derivative instruments).

II. За другою ознакою фінансові інструменти поділяються на інструменти 3 негайною поставкою касові, або спотові (spot, cash), та строкові інструменти (termine instruments), оскільки $є$ контрактами на купівлю-продаж базових фінансових інструментів у майбутньому за цінами або курсами, погодженими в момент укладання таких контрактів.

III. Деривативи - це фінансові контракти або інші документи, що походять із (базуються на) інших фінансових інструментів(ах), які називають базовими інструментами. Основою такого фінансового інструменту (контракту) можуть бути активи (наприклад, товари, акції, житлові застави, нерухоме майно, облігації, позики), індекси (на відсоткові ставки, валютні курси, фондові індекси, індекси споживчих цін) або інші умови. Кредитні деривативи походять від позик, облігацій чи інших форм кредитування.

IV. Похідні фінансові інструменти, до яких відносять: 1) інструменти, розрахунки за якими провадитимуться у майбутньому; 2) інструменти, вартість яких змінюється внаслідок змін відсоткової ставки, курсу цінних паперів, валютного курсу, індексу цін, кредитного рейтингу (індексу) або інших змінних, що є базисними; 3) інструменти, які не потребують початкових інвестицій.

Отже, основними видами похідних фінансових інструментів, є форварди, ф’ючерси, опціони та свопи. Похідні фінансові інструменти поділяють на умовні (біржові та позабіржові опціони, а також різні види страхування контрактів) і безумовні (ф'ючерси, форварди та свопи).

У країнах СС не вживається термін похідні, а використовується термін строкові фінансові інструменти. До таких інструментів відносять форвардні контракти (forward), ф'ючерсні (future) біржові та опціонні (option) біржові, позабіржові контракти та свопи (swap).

А фінансові інструменти, які сьогодні широко застосовуються у зарубіжній практиці, можна поділити на п'ять груп:

1. Пайові цінні папери (акції та сертифікати інвестиційних фондів).

2. Боргові зобов'язання (облігації, казначейські зобов'язання, комерційні папери, векселі, депозитні сертифікати).

3. Похідні фінансові інструменти (форварди, ф'ючерси, свопи, опціони).

4. Гібридні інструменти (конгломерати простих інструментів, наприклад гібрид процентних та валютних інструментів).

5. Синтетичні інструменти (опціон на ф'ючерсний контракт, дво-валютна облігація, синтетична акція тощо).

Згідно цієї теми, найбільш доцільно розглянути принципи формування і функціонування ринку цінних паперів у державі [9, с. 110 - 111], як:

- принцип соціальної справедливості, що будується на забезпеченні створення рівних можливостей без монопольних проявів;

- принцип надійності захисту інвесторів, тобто створення умов для реалізації інтересів суб'єктів ринку цінних паперів;

- принцип урегульованості, тобто створення гнучкої і ефективної системи регулювання ринку цінних паперів;

- принципом $є$ контрольованість, тобто створення надійно діючого механізму обліку i контролю на ринку цінних паперів.

- принцип ефективності, тобто максимального реалізація потенційних можливостей ринку цінних паперів щодо мобілізації фінансових ресурсів, їх розміщення у перспективних сферах національної економіки, що сприятиме забезпеченню іiі прогресу, задоволенню життєвих потреб населення; 
- принцип правової упорядкованості - 3 правової точки зору, це створення розвиненої правової інфраструктури забезпечення діяльності ринку цінних паперів, яка чітко регламентуватиме правила поведінки, взаємовідносин його суб'єктів;

принцип регулювання конкуренції, що означає забезпечення необхідної свободи підприємницької діяльності інвесторів, також емітентів і ринкових посередників.

У США в деякій мірі ці принципи, які були фундаментом для започаткування i розвитку фондової біржі, з часом постійно нівелювалися, в результаті чого відбулися негативні наслідки для іiі економічної системи.

A початок правління Джорджа Бушамолодшого позначився на поглибленні кризових явищ на економіці США, що відзначалося зростанням платіжного дисбалансу через необгрунтовану кредитну політику комерційного банку, через збільшення фінансового дефіциту виникали труднощі у погашенні боргових зобов'язань, а також інтенсивні коливання біржових індексів на фондовому ринку, які призводили до знецінення акцій. Також слід зазначити значний вплив політичних факторів на економіку США, які посилили негативні тенденції.

Далі повертаємось у 1929 р.: де під час початку Великої депресії негативні тенденції у економіці США у деякій мірі були схожими: біржовому краху на передував спекулятивний бум у 1920-их рр., визваний купівлею цінних паперів мільйонним населенням США, під дешеві кредити на акції, які американські банки безупинно видавали. Попит шалено поглинав пропозицію, спекулянти тягнули тренд все вище на протязі 9-ти років, Dow Jones виріс на 400\% сягнувши 380 базисних пунктів, тоді банки обіцяли інвесторам 2-4\% в день, що спричинила високу спокусу і внаслідок чого відбулося роздуття вартості кредитів. Звичайно, банківські кредити були доступні з обліковою ставкою $3 \%$, тобто, $з$ таким ростом була змога не то що покрити зобов'язання, але й їх перепогасити. Тому ситуація, коли моральний ризик перевищує здоровий глузд, завжди призводить до непередбачуваних наслідків - ФРС стали свідками того, як відбувся ажіотаж щодо кредитування населення ще у 1928 році, прийнявши міру підвищити облікову ставку до 5\%, але оскільки регулятивні важелі банківської системи виявилися слабими, то після чергового кризового явища у 1929ому році ажіотаж призвів до занепаду спочатку самої банківської системи, а пізніше - і економіки в цілому [7, с. 33]. Тут причина банківського та економічного колапсу у державі криється не у регулятивних важелях, а діями та інтересами самих банківських установ, коли дав збій звичайний «економічний ринковий механізм» - в результаті чого інвестори почали втрачати капітал, через падіння цін на акції провідних компаній до $70 \%$, а до кінця року фондовий ринок втратив 40 млрд. \$, тобто це цілком об'єктивна цифра, зважаючи на те, що в подальші роки збанкрутувало 4835 банків. Отже виявилося, що видача банками кредитів за відсотковою ставкою 4\% в день, ігноруючі ризикові активи, які на сьогоднішній день в біржових колах називаються «хайпами» (високоризикові фінансові проекти, створені для інформаційного ажіотажу та роздування економічного активу), призвела до великих негативних наслідків у банківській сфері, в результаті чого економіка США зазнало великого економічного краху.

Також доцільно навести окремий приклад на державному рівні: під час правління Білла Клінтона економіка США зростала стрімкими темпами, рівень інфляції скорочувався, а бюджет країни перебував у профіциті, але це ще не означало, що після правління державою Біллом Клінтоном залишився економічний прогрес. При таких умовах інтесифікація нарощувалась разом 3 високотехнологічним «доткомом» (бум на ріст інтернет-бізнесу) [2, с. 136; 3 , с. 100], внаслідок якого виявилося, що з початку 2000 рр. відбулося стрімке та неминуче знецінення вартості акцій американських інтернет-компаній (рис. 1).

До цих негативних тенденцій, звісно, додалися й політичні чинники, а також недосконале державне управління комерційними банками i фондовим ринком у США, що супроводжувалося падінням економічних показників, як знецінення акцій й фінансових інструментів на фондових біржах, що набували загрозливого масштабу поряд із різким здорожченням кредитних ставок й падіння оборотів грошових коштів [4, с. 27].

Крім цього, в подальшому під час президентства Джорджа Буша-молодшого у США відбулася низка природніх катаклізмів, які завдали збитків у розмірі 125 млрд. \$.

Подібним чином через низку фінансових та біржових махінацій, які слабо контролювалися державними установами, економіка США і фондовий ринок зокрема втрачали значну суму коштів та обвалювалися внаслідок знецінення облігацій на 60 \% через те, що залишалися непроданими й мали високий ступінь ризику [5, с. 118], яким підкуплені та недобросовісні рейтингові агенства присвоювали найвищий рейтинг. Але найгірше те, що саме ці облігації разом із державними цінними паперами були об'єднані в пул (сегмент для купівлі-продажу облігацій) підлягали забезпеченню державою. В результаті чого різко зросли відсоткові кредитні ставки, а для звичайних громадян стало неможливо покривати вартість кредитів, аналогічно тому, як це відбулось у 1929-ому році (рис. 2).

Ще слід зазначити, що через негативні тенденції у економіці США, які виникли внаслідок обвалу на фондовому ринку у початку 2000-х рр. уряд виділяе фінансову допомогу основним системоутворюючим банкам, щоб поліпшити стан в економіці - але за рахунок видачі кредитів та підвищення кредитообігу грошей.

На основі цього дев'ять банків отримали дотацію казначейства у розмірі 125 млрд. доларів, і це призвело до локалізації на 75 \% всіх банківських активів США у банківську сферу. 


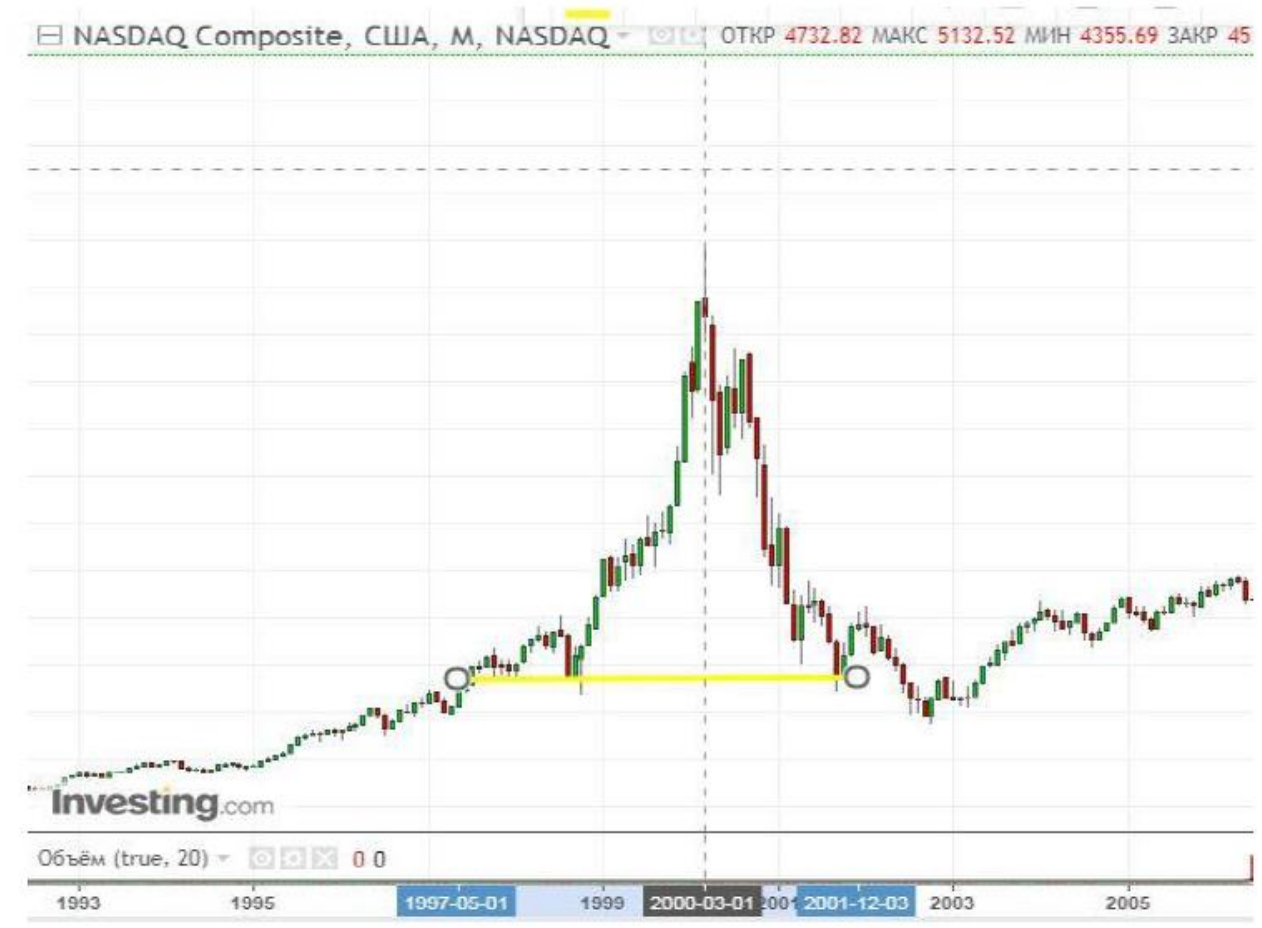

Рис. 1. Динаміка тренду американського індексу NASDAQ під час «доткому» [10]

Але ці кошти комерційні банки використали не за призначенням - на покриття своїх збитків, які виникали i наростали при здійсненні звичайних банківських операцій.
Внаслідок цього фондовий ринок ще дужче продовжував обвалюватися, що призвело до зростання безробіття більш ніж на $10 \%$, і втратою мільйонами сімей свого житла та майна.

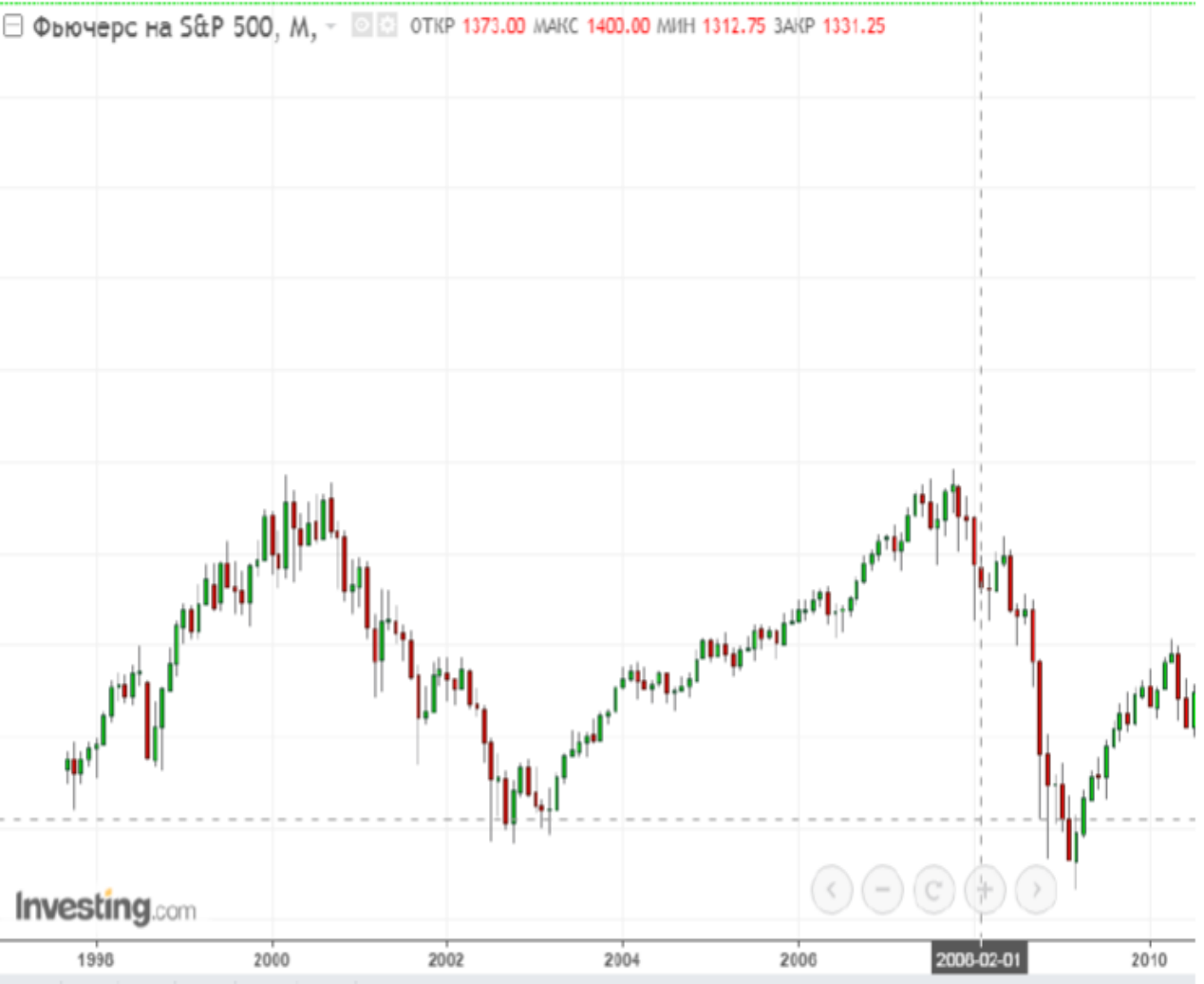

Рис. 2. Падіння тренду американського індексу S\&P500 під час іпотечної кризи [11] 
Отже, загальні причини кризових подій на ринках цінних паперів у США характеризуються таким чином:

недосконала кредитна політика комерційних банків й збільшення кредитних операцій 3 меншим рівнем забезпеченості;

- складна й слабкопередбачувана державна політика при формуванні економічної інфраструктури щодо діяльності фінансових та банківських установ;

- дисбалансованість товарно-грошових обмінів у економіці США та стрімке зростання державного боргу.

Варто було б звернути уваги на ключові причини, які викликали кризові події на ринках цінних паперів США і запропонувати регуляторні заходи щодо покращення ситуації.

Але, щоб врахувати ці вищезазначені причини як для інших країн, так i вітчизняного простору, доцільно здійснити такі заходи: у самих фондових біржах доцільно оптимізувати інформаційне забезпечення, які наприклад стосуються тих процесів, що відбуваються в країні і мають вплив на вартість цінних паперів та фінансових інструментів, а також поліпшити оціночні критерії на підставі поточних подій та ситуацій, які відбуваються у країні - особливо під час здійснення операцій на фондовому ринку, укладення угод i торгівля фінансовими інструментами, для мінімізації кількості помилок і збільшення прибутковості інвестування.

Отже, на думку автора, наукова і практична цінність удосконалення ринку цінних паперів на прикладі США має такі положення:

удосконалення процесу розрахунку ринкової вартості цінних паперів 3 метою виявлення джерел, резервів та факторів збільшення доходності операцій 3 ними, а також оптимізації їх обігу та розміщення;

- оптимізація процесу дисконтування операцій 3 цінними паперами та диверсифікація фінансових інструментів у торгах на фондовому ринку;

- групування інформаційного забезпечення, які впливають на фондовий ринок 3 метою забезпечення здатності досягати ефективності біржових торгів і збільшити обсяг грошових вливань в ринок капіталу. Це є найважливіше не тільки для учасників фондового ринку, але й для економіки держав.

Поряд 3 цим, слід обгрунтувати такі методичні засади й інструментів регулювання ринку цінних паперів, як:

- упорядкування методики оцінки вартостей цінних паперів та фінансових інструментів 3 врахуванням коливання їх курсів;

-групування об'єктів оцінки, які закладаються у вартість цінних паперів, за рівнем ліквідності або здатності фінансового забезпечення на період економічних та політичних ситуацій, які трапляються в країні;

- постійно переглядати властивості фондових індексів у залежності від зміни вартостей цінних паперів, фінансових інструментів та коливань валютних курсів.

Висновки та перспективи подальших досліджень. Стан функціонування ринку цінних паперів у США на сьогоднішній день відображає ті реалії i фундаментальні принципи, якими були побудовані фінансові ринки у 50 - 90-ті рр. ХХ ст. Саме це вищезазначене й уповільнює стрімку перебудову й осучаснення фінансових ринків, характерний для останніх кількох років.

Наукова новизна полягає у обгрунтуванні ролі фондового ринку в розвитку економіки держави, як за рахунок впливу державних установ та участі комерційних банків у операціях з цінними паперами, які відображаються на коливання відсотків, залучення кредитів, рейтингове оцінювання економіки країни.

У цій статті теоретична значимість фондового ринку США розкриває процес державного регулювання свідчить про недосконалість процесу поліпшення операцій на фондовому ринку.

Звідси випливає, що практична значимість полягає в тому, щоб в подальшому удосконалити існуючий ринок цінних паперів та забезпечити іiі ефективність, доцільно розробити механізм управління економікою держави із врахуванням успішних тенденцій розвитку i темпів зростанням економіки, а також негативного досвіду і на основі цього наслідків. Поряд із практичною значимістю $\epsilon$ можливість виділити такі перспективи у процесі подальших досліджень, де особливу увагу слід звернути на такі тенденції, які виникають внаслідок впливу держави та банківських установ на фондовий ринок.

Тому на основі вищезазначених висновків потрібно сформувати такі пропозиції:

1. Уніфікувати процес розрахунку фондового індексу у відповідності до кращої світової практики, щоб поліпшити оцінку процесів, які відбуваються на фондовому ринку та операцій підприємства 3 цінними паперами;

2. Удосконалити процес розрахунку ринкової вартості цінних паперів 3 метою виявлення джерел, резервів та факторів збільшення доходності операцій з ними, а також оптимізації їх обігу та розміщення.

3. Слід зазначити характеристику фондового ринку України, який у порівнянні зі фондовими ринками високорозвинених країн, наприклад, США, Великобританії, Німеччини, Франції $є$ недостатньо розгалуженим за операціями та застосуванням фінансових інструментів, має менший розмір, меншу кількість учасників та ін. Виходячи 3 цього, слід вітчизняний фондовий ринок постійно удосконалювати у відповідності кращих практик світового фондового ринку, оптимізувати i розширити кількість лише тих операцій, які сприятимуть підвищенню дохідності за рахунок розміщенню фінансові інструменти у більш цінні активи, збільшують обсяг грошових потоків, в основному зменшують ризиковість розміщення грошових коштів, мають компенсаційні властивості цінних паперів у період зростання інфляції та ін. Тут цінним $\epsilon$ досвід щодо застосування досвіду зарубіжних фондових бірж для впровадження у 
вітчизняний фондовий ринок, такі як обіг грошових коштів i розміщення акцій для торгів від підприємств-емітентів, розрахунку фондових індексів та ін.

\section{Література}

1. Стиглиц Джозеф Юджин. Великое разделение. Неравенство в обществе, или Что делать оставшимся 99\% населения? / Стиглиц Джозеф Юджин; пер. с англ. Ф. А. Исрафилова. М.: Эксмо, 2016. 480 с. (Тор Economics Awards)

2. Фондовый рынок (Рынок ценных бумаг): учеб. пособие / Кондрашихин А.Б. и др. К.: Центр учебной литературы, 2008. 376 с.

3. Поважний О.С., Орлова Н.С., Свєчкіна А.Л. Цінні папери і фондовий ринок: навч. посібник. Львів: Магнолія 2006, 2010. 361 с.

4. Рубцов Б.Б. Зарубежные фондовые рынки: инструменты, структура, механизм функционирования. М.: ИНФРА-М, 1996. 304 с.

5. Хагстром Роберт, Уоррен Баффет. Как 5 долларов превратить в 50 миллиардов. Стратегия и тактика великого инвестора / Хагстром Роберт, Уоррен Баффет. / под ред. В. А. Кравченко; пер. с англ. Н. Г. Яцюк. М.:Эксмо, 2010. 304 с.

6. Льюїс Майкл. Flash Boys. Ринок цінних... секунд: революція на Уолл-стрит / Льюїс Майкл; пер. 3 англ. А. Рогози. Харків : Клуб Сімейного Дозвілля, 2017. 296 с.

7. Фондовые рынки США : основные понятия, механизмы, терминология. М.: Церих-ПЭЛ, 1992.184 с.

8. Гох Лео. Как реально работает фондовый рынок. Секретное руководство для инвестора-«партизана»/ Гох Лео.; пер. с англ. В. А. Сомило. Днепропетровск: Баланс Бизнес Букс, 2006. 368 с.

9. Пугачова Є.В. Принципи формування і функціонування ринку цінних паперів в Україні // Науковий вісник Ужгородського національного університету. Серія ПРАВО. 2014. Вип.24, Т.3. С. 108-111.

10. Как открыть счет на бирже Nasdaq / How to open an account on the Nasdaq. URL:https://teslagroup.com.ua/kak-otkryt-schet-na-birzhe-nasdaq/ (дата звернення - 28.11.2018 p.)

11. Калачова Г., Колесніченко О. «Чорний тиждень» для фінансових ринків: тимчасовий струс чи початок нової кризи // Українська правда. Серія: Економічна правда. 2018. 9 лютого. URL: https://www.epravda.com.ua/publications/2018/02/9/ 633908/ (дата звернення 5.12.2018 p.)

12. Про цінні папери та фондовий ринок: Закон України від 23 лютого 2006 року № 3480-IV : за станом на 15.05.2018 року № 2418-VIII. URL: http://zakon.rada.gov.ua/laws/show/3480-15 (дата звернення - 11.12.2018 p.)

13. Про державне регулювання ринку цінних паперів в Україні: Закон України від 30 жовтня 1996 р. № 448/96-BP : за станом на 15.05.2018 року № 2418-VIII. URL:http://zakon.rada.gov.ua/laws/show/448/96$\% \mathrm{D} 0 \% \mathrm{~B} 2 \% \mathrm{D} 1 \% 80$ (дата звернення - 11.12 .2018 р.)

14. Цивільний кодекс України від 16 січня 2003 р. № 435-IV : за станом на 23.11.2018 року № 2628VIII. URL:http://zakon.rada.gov.ua/laws/show/435-15 (дата звернення - 11.12.2018 p.)

15. Господарський кодекс України від 16 січня 2003 р. № 436-IV. за станом на 17.01.2019 року № 2672 VIII. URL:http://zakon.rada.gov.ua/laws/show/436-15 (дата звернення - 5.02.2019 p.)

\section{Горбаневич В.Л.}

аспирант

кафедра финансов, банковского дела и страхования

Львовский торгово-экономический университет

ул. Туган-Барановского, 10, г. Львов, 79000

E-mail:vetal11gl@gmail.com

Иванюта П.В.

доктор наук по государственному управлению, доцент

кафедра менеджмента

Винницкий кооперативный институт

ул. Академика Янгеля, 59, г. Винница, 21009

E-mail: ur6hdc@gmail.com

\section{РОЛЬ РЫНКА ЦЕННЫХ БУМАГ В ЭКОНОМИКЕ ГОСУДАРСТВА (HА ПРИМЕРЕ США)}

Обоснована необходимость исследования рынка ценных бумаг, которая состоит в раскрытии процессов функционирования рыночных отношений в экономике государства, где основное внимание 
уделяется изменению процентных ставок, стоимости денежных средств и ценных бумаг, кредитной политики коммерческих банков и т.п., отражающиеся на экономике государства - на примере США.

Сущность функционирования фондового рынка в США состоит в разделении на биржевой и внебиржевой, или, иными словами, первичный и вторичный рынки. Естественно, фондовый рынок в той или иной стране обозначается, прежде всего, показателями капитализации экономики государства, ее долей в ВВП, а также долей финансирования капиталовложений за счет эмиссии акций, которые оборачиваются при осуществлении биржевых торгов. Кроме этого, мировая доля капитализации экономики государства за счет биржевых торгов 70 \% осуществляется именно у США. Потому что у США фрондовая биржевая деятельность имеет широкое распространение во всем мире и является более крупнейшей финансовой системой в стране - по размеру, объему торговых операций, количеству участников и т.п., занимающее доминирующее положение в отношении использования финансовых инструментов и быстрых денежных потоков.

Следует также отметить и специфику государственного регулирования рынка ценных бумаг в США, что предполагает вмешательство государственных учреждений в деятельность фондовых бирж и выделение средств на их существование и развитие.

Следовательно, фондовый рынок в каждой стране характеризирует не только торги на бирже, но и такие вспомогательные процедуры, как уровень прозрачности торгов, доступом к информационному обеспечению, наличия современных технических средств и перечня имеющихся услуг, ценовой политики, колебания курсовых разниц и т.д. Это создает эффеект закрытого пространства осуществления быржевых торгов на фондовом рынке по необходимости улучшать услуги в процессе их предоставления участникам, но при условии конкуренции между ими по причине ограниченого спроса ценных бумаг и применению на их основе финансовых инструментов.

Ключевые слова: ценные бумаги, акции, банки, фондовый рынок, экономика.

\author{
Horbanevych V. \\ Postgraduate Student \\ Department of Finance, Banking and Insurance \\ Lviv Trade and Economic University \\ Tugan-Baranovsky str., 10, Lviv, 79000 \\ E-mail: vetal11gl@gmail.com \\ Ivanyuta $\mathbf{P}$. \\ Doctor of Public Administration, Associate Professor \\ Department of Management \\ Vinnitsa Cooperative Institute \\ Akademyka Janghelja str.,59, Vinnitsa, Ukraine,21009 \\ E-mail: ur6hdc@gmail.com
}

\title{
ROLE OF SECURITIES MARKET IN THE STATE ECONOMY (US EXAMPLE)
}

The need to study the securities market, which consists in disclosing the processes of functioning of market relations in the state's economy, where the focus is on changes in interest rates, cost of cash and securities, credit policies of commercial banks, etc., affecting the state's economy - on US example, has been justified.

The essence of the functioning of the stock market in the United States is to divide into stock and over-the-counter, or, in other words, primary and secondary markets. Naturally, the stock market in a particular country is indicated primarily by indicators of the capitalization of the state's economy, its share in GDP, as well as the share of financing capital investments by issuing shares that turn around when trading is conducted.

In addition, the global share of capitalization of the state's economy through stock exchange trading of $70 \%$ is carried out precisely in the USA Because the US stock exchange activity is widespread throughout the world and is more than the largest financial system in the country - in size, volume of trade, number of participants, etc., dominating in the use of financial instruments and fast cash flows.

The specifics of state regulation of the securities market in the United States, which involves the intervention of government agencies in the activities of stock exchanges and the allocation of funds for their existence and development should also be noted.

Consequently, the stock market in each country characterizes not only trading on the stock exchange, but also such supporting procedures as the level of trading transparency, access to information support, the availability of modern technical means and the list of available services, pricing policy, fluctua- 
tions in exchange differences, etc. This creates the effect of a closed space for the stock exchange trading on the stock market when it is necessary to improve services in the process of providing them to participants, but subject to competition between them due to the limited demand of securities and the use of financial instruments on their basis.

Keywords: securities, stocks, banks, stock market, economy.

\section{References}

1. Stiglits, D. Yu. (2016). Velikoe razdelenie. Neravenstvo v obschestve, ili Chto delat ostavshimsya 99\% naseleniya? (F. A. Israfilova, Trans.). Moscow: Eksmo.

2. Kondrashihin, A. B. (2008). Fondovyiy ryinok (Ryinok tsennyih bumag). Kiev: Tsentr uchebnoy literaturyi.

3. Povazhnyi, O. S., Orlova, N. S., \& Sviechkina, A. L. (2010). Tsinni papery i fondovyi rynok. Lviv: Mahnoliia.

4. Rubtsov, B. B. (1996). Zarubezhnyie fondovyie ryinki: Instrumentyi, struktura, mehanizm funktsionirovaniya. Moscow: INFRA-M.

5. Hagstrom, R., \& Baffet, U. (2010). Kak 5 dollarov prevratit v 50 milliardov. Strategiya i taktika velikogo investora (V. A. Kravchenko, Ed.; N. G. Yatsyuk, Trans.). Moscow: Eksmo.

6. Liuis, M. (2017). Flash Boys. Rynok tsinnykh... sekund: Revoliutsiia na Uoll-stryt (A. Rohozy, Trans.). Kharkiv: Klub Simeinoho Dozvillia.

7. Fondovyie ryinki SShA: Osnovnyie ponyatiya, mehanizmyi, terminologiya. (1992). Moscow: Tserih-PEL.

8. Goh, L. (2017). Kak realno rabotaet fondovyiy ryinok. Sekretnoe rukovodstvo dlya investora«partizana» (V. A. Somilo, Trans.). Dnepropetrovsk: Balans Biznes Buks.

9. Puhachova, Ye. V. (2014). Pryntsypy formuvannia i funktsionuvannia rynku tsinnykh paperiv v Ukraini. Naukovyi Visnyk Uzhhorodskoho Natsionalnoho Universytetu, 3(24), pravo, 108-111.

10. How to open an account on the Nasdaq. Retrieved November 28, 2018, from https://teslagroup.com.ua/kak-otkryt-schet-na-birzhe-nasdaq/

11. Kalachova, H., \& Kolesnichenko, O. (2018, February 9). «Chornyi tyzhden» dlia finansovykh rynkiv: Tymchasovyi strus chy pochatok novoi kryzy. Retrieved December 5, 2018, from https://www.epravda.com.ua/publications/2018/02/9/ 633908/

12. Pro tsinni papery ta fondovyi rynok: Zakon Ukrainy vid 23 liutoho 2006 roku № 3480-IV : Za stanom na 15.05.2018 roku № 2418-VIII. (2018). Retrieved December 11, 2018, from http://zakon.rada.gov.ua/laws/show/348015

13. Pro derzhavne rehuliuvannia rynku tsinnykh paperiv v Ukraini: Zakon Ukrainy vid 30 zhovtnia 1996 r. № 448/96-VR : Za stanom na 15.05.2018 roku № 2418-VIII. (2018). Retrieved December 11, 2018, from http://zakon.rada.gov.ua/laws/show/448/96-вp

14. Tsyvilnyi kodeks Ukrainy vid 16 sichnia 2003 r. № 435-IV : Za stanom na 23.11.2018 roku № 2628-VIII. (2018). Retrieved December 11, 2018, from http://zakon.rada.gov.ua/laws/show/435-15

15. Hospodarskyi kodeks Ukrainy vid 16 sichnia 2003 r. № 436-IV. za stanom na 17.01.2019 roku № 2672VIII. (2019). Retrieved February 5, 2019, from http://zakon.rada.gov.ua/laws/show/436-15

Received 10 February 2019

Approved 24 February 2019

Available in Internet 19.03.2019

Цитування згідно ДСТУ 8302:2015

Горбаневич В.Л., Іванюта П.В. Роль ринку цінних паперів в економіці держави (на прикладі США) // Економіка харчової промисловості. 2019. Т.11, вип. 1. С. 94-104; doi: 10.15673/fie.v11i1.1300

Cite as APA style citation

Horbanevych V., \& Ivanyuta P. (2019). Role of securities market in the state economy (US example). Food Industry Economics, 11(1), 95-104; doi: 10.15673/fie.v11i1.1300 